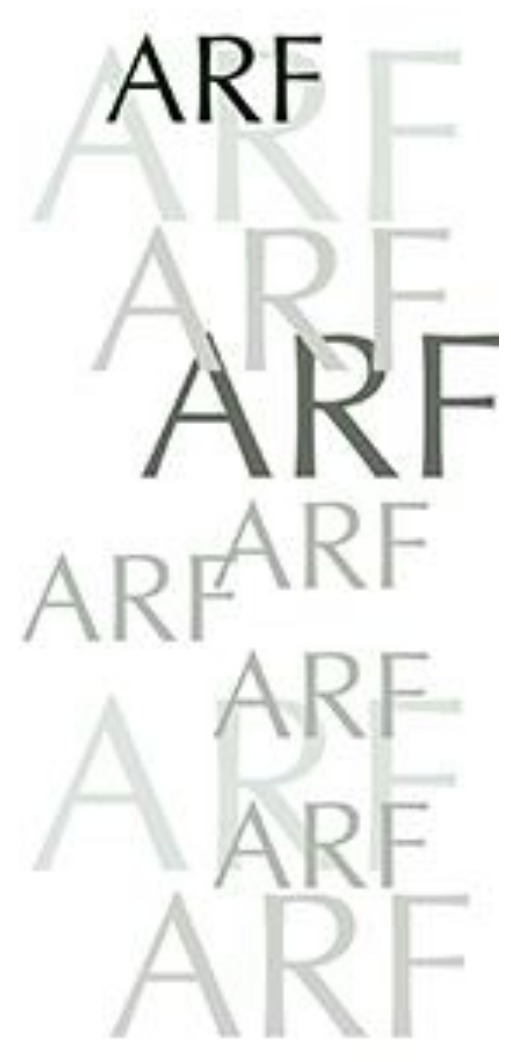

\title{
The Tall Building and Urban Space
}

\author{
In light of two modernist case studies
}

\author{
Minna Chudoba \\ Tampere University, School of Architecture \\ minna.chudoba@tuni.fi
}

\begin{abstract}
If public spaces in the urban environment are seen as extensions of one's home, then what role do tall buildings play in this setting? In terms of space, they can have various roles. They are visible from afar and often act as landmarks, but at the same time they give one a possibility to see the urban whole in its entirety, from above.

One of most iconic images of modern urban planning and modern urban space - Le Corbusier's plan for Paris - is shown from such a vantage point, depicting an urban area dotted with individual buildings set within a continuous spatial field. This modern space has often been described as open and homogeneous. The simplified general interpretation has further been complemented by the concept of heterogeneous space, paving the way for a more diverse spatial theory. Heterogeneous space has brought much needed complexity to interpretations of architectural space.

Modernist space is revisited in this article, explored through two particular cases. In addition to Le Corbusier, the study includes the work of another architect and urban planner of the early $20^{\text {th }}$ century, Eliel Saarinen. The role of tall buildings in the designs and writings of the two architects is compared, with a specific focus on the spatial implications of these buildings in the cityscape. The comparison illustrates the fact that modern architects were not unanimous in their visions of urban space, although they shared the knowledge of a contemporary spatial theory.
\end{abstract}

Keywords: tall buildings, urban space, modern architecture.

\section{Introduction}

Finnish cities have been looking upward in the past decade, answering the need to densify urban areas and provide more housing for a growing population. At the same time, city dwellers, even families with small children, have come up with their own unique solutions to urban living, sometimes even opting for less dwelling area in exchange for a well-situated apartment (Lapintie 2017; Suomen Hypoteekkiyhdistys 2018, 3). The latter has put forth new challenges for public and semi-public urban spaces, as well as caused changes in the preferred services. For example, cafes and restaurants seem to have become the number one service request for a residential area - this reflects their rising importance as places for meeting and working (Suomen ympäristökeskus 2017).

When public and even semi-public places in the urban environment are seen as extensions of one's home, these spaces should meet the various needs of the inhabitants. How should public spaces be designed, furnished, and then used? Are they connected to form networks, and should they be specifically marked in 
the urban context? Tall buildings could possibly play a role in this. After all, as landmarks they are visible in the cityscape. At the same time, they offer a possibility to see the urban landscape from above, providing a view to be appreciated collectively - if the design of the tall building offers at least a semipublic point of observation. In terms of space, tall buildings can be accents that have a role in directing spatial flows, while providing this platform for appreciating open space with a controlling gaze.

The aim of this article is to look at the tall building question from a historical perspective, thus providing a background for understanding the current spatial possibilities offered by this controversial building type. A summarizing overview of modern spatial theory is offered first as a base for the study of drawings and texts of two architects: Swiss-French architect Le Corbusier (Charles-Edouard Jeanneret) and Finnish-American architect Eliel Saarinen. These architects' works illustrate the different attitudes to tall buildings and space in the early $20^{\text {th }}$ century; both architects used high-rises or skyscrapers in their urban plans during the 1920s, and both supplemented their designs with text. The question asked is: What role did tall buildings have - spatially - in the visions of these modern urban planners? To answer the question, two specific designs are studied: Le Corbusier's visionary plan for the center of Paris (1925) and Eliel Saarinen's plan for Chicago's lakefront (1923). The study of these urban plans is complemented by the planners' texts, which give additional insight into their understanding of space as an element in urban compositions. In revisiting modern urban space and comparing the two example cases, the concept of heterogeneous space is used to complement the view of homogeneous modern urban space. A variety of views is necessary for understanding the complex spatial issue of tall buildings in the city.

\section{Modern space and its urban implications}

Space continues to be one of the most important central concerns in teaching architecture and urban design. First year students of urban planning learn definitions of space and then begin designing with it. It is, after all, both design material - architects even speak of the materiality of space - and a concept that influences design. In urban design and planning, the space concept is broadened in scale and painted with varying degrees of publicness. Public life brings forth people and their experiences of collectively perceived urban space. At the same time, individuality is present - one perceives as an individual. Architects speak of townscape, which implies visual connotations, an individual viewpoint, also a sense of being somewhere, being placed. For an architect or an urban planner, situating oneself in the urban space is an approach necessary for design-orientation.

When the space concept is paired with time, we have an idea of space that has been shaped by the modernist architectural tradition. The space-time continuum of physics received its architectural interpretation (on space-time, see Van de Ven 1978, 43-48; Giedion 1941/1974, 815-869; on Giedion's influence, see Kruft 1985/1994, 435; Vidler 2001, 194-199). While modernist theories of space are by no means unanimously uniform, modernist space has been called homogeneous (Hight et al. 2009, 10; Hara cited in Wakabayashi 2019). Homogeneous space, by definition, owes much to mathematical understanding of space. In architecture, it is linked to geometrical constructions of perspective drawing, which presuppose the existence of a consistent medium where objects may be located (Mitrović 2004, 424). As this view has its limitations, the concept of heterogeneous space has been used to pave the way for a spatial theory beyond a simplified understanding of modernist space. Nevertheless, even this concept has been described in relation to the modernist tradition, more often with what it is not, instead of what it is. Heterogeneous space has, in any event, offered a more diverse understanding of architectural space, bringing necessary complexity to contemporary interpretations, especially in the urban scale. 
Cornelis van de Ven has claimed in his classic book Space in Architecture (1978), that space did not really exist in architectural theory before the late 1800s; only then did it become an artistic concept. With architecture understood as an art, space became the embodiment of human activity inside a shell provided by architecture. (van de Ven 1978, xi-xiv; also noted by Collins 1965, 285; cited in Mitrović 2004, 425.) Space was, however, used and understood long before it was taken into architectural theory as an artistic concept. Van de Ven $(1978,46,243$, with reference to Einstein) offered three premises of physical space:

- Space as place

- Three-dimensional absolute space - space as container

- Four-dimensional relative space - space as a field

The first premise was explained already by Aristotle in his theory of place (topos). This concept depended on material objects; empty space had no meaning in space understood through place. (van de Ven 1978, 15, 46.) Absolute space, on the other hand, was an independent concept. Space was seen as infinite, the container of all material objects. (van de Ven 1978, 30.) Relative space was a system of relations between coexisting things - here space became a field. (van de Ven 1978, 33.) However, the division was largely a theoretical, simplified construct. According to van de Ven (1978, 46), all three ideas of space were present simultaneously in architecture. Pure visualizations of the premises simply did not exist.

Sigfried Giedion, who has done much to define the very concept of space in modern architecture, similarly used a three-part division in his book Space, Time \& Architecture (1941/1974, Iv-Ivi). He found space both as interplay between volumes and space as interior space in the architecture of ancient civilizations, but in his opinion, with the advent of modern architecture something entirely new had become the focus of spatial understanding. Movement was this essential component in experiencing contemporary architecture and urban space. (Giedion 1941/1974, Ivi, 826, 850-853.) As his book was written to grasp the contemporary architectural scene and define its aims, the focus was less on the understanding of historical evolution of spatial concepts, and more on contemporary synthesis. The single viewpoint perspective had been abolished and modern architecture was trying to capture the essence of its time. This essence was motion, since "the space-time feeling of our period can seldom be felt so keenly as when driving." (Giedion 1941/1974, 826). This can be seen in much earlier texts already ${ }^{1}$, for example, in Le Corbusier's Urbanisme, where he described moving in an urban environment, first as a pedestrian, then becoming elated with the speed of movement and the power represented by moving vehicles (Le Corbusier 1924/ 1987, xxiii). These descriptions seem to indicate that space was no longer just a container or simply interior space. Even so, modern architecture's attitude to space has been criticized for concentrating on mass and treating space around these masses as immaterial. In this case, the modern space-time-concept has been seen as a version of Newtonian view of the world as objects in a void (Kuoppamäki 1993, 57).

\section{Skyscraper types and space}

The tall building type had been approached with varying attitudes even with the onset of early skyscrapers in the late 1880s and early $1900 \mathrm{~s}^{2}$. In New York, the race for the tallest building had resulted in clusters of skyscrapers, where the height differences could easily be compared as the buildings were constructed

\footnotetext{
${ }^{1}$ Van de Ven $(1978,84-90)$ mentions even earlier $19^{\text {th }}$ century writers on the topic of space and time or mobility in space, for example: Adolf von Hildebrand and August Schmarsow.

${ }^{2}$ The story of skyscrapers in the United States has been touched by various authors, but a detailed account is found in Thomas A.P. van Leeuwen's The Skyward Trend of Thought. The Metaphysics of the American Skyscraper (1988). A European outlook on the issue has been included in JeanLouis Cohen's Scenes of the World to Come: European Architecture and the American Challenge, 1893-1960 (1995).
} 
in close proximity to each other (van Leeuwen 1988/1990). These skyscraper clusters - and the dark urban canyons they made of the city streets - were criticized especially in Europe (Chudoba 2011, 56-57). The Stadtkrone idea promoted by Bruno Taut (1919) had given the tall building a central role in urban design. Tall building as a landmark, a focal point in an urban composition, was seen by many architects as the most proper use for the building type (Chudoba 2011, 57). A landmark building was helpful in orientation on the street level, and also gave a possibility to observe the vastness of open space - or nearness of the sky, as noted by Le Corbusier's in his quote on the major materials of city planning ${ }^{3}$. By the early 1920s, Le Corbusier had drafted his famous plan for Paris, where tall buildings were neither landmarks nor clusters, but building blocks in an ordered urban composition. Skyscraper city was shown in bird's eye views as a field of tall buildings in ordered rows, all equidistant from each other. This field ${ }^{4}$ of skyscrapers allowed for space to move freely.

In his seminal book Space, Time \& Architecture, Giedion placed major importance on the idea of motion in connection with space. He linked space with time, and this demanded a new way of seeing. To explain the role of motion in experiencing architecture, Giedion (1941/1974, 850-853) chose a composition which included a skyscraper. New York's Rockefeller Center, built in 1932-39 could not, as Giedion described it, be understood at a single glance, unlike many previous examples of tall buildings had been. For Giedion, the composition of buildings and the adjoining spaces had a new complexity, a time-lapse quality that could only be experienced through movement around the group of buildings. The space-time concept gave a new view of the example: a tall building was not just as an object to be contemplated, but also involved with the spaces and buildings around it, and with the movement and distances required for experiencing the architecture in its urban context. Space was linked with the object. In this case the objects were tall buildings and the spaces mediated their relationship to context.

All three attitudes to tall buildings - the cluster, the landmark, the field - had to deal with the tall building's role in the city. Each attitude resulted in a different use of the building type as a design element in an urban composition. Tall buildings have always been emblems of power, often financial. Height leads to image-generating visibility, especially if the skyscraper is of the landmark variety. A silhouette of skyscrapers - mostly associated with the cluster type is thought to be an optimistic sign of growth and prosperity. The urban density such a silhouette implies is spatially demanding, therefore, the field type in its modernist apartment block guise was used as a solution to this challenge. When tall buildings were used in various ways as elements in an urban composition, the spatial implications of the different design choices were also manifold. The clusters of skyscrapers blocked light to the streets below, resulting in unique urban spaces: dark narrow ravines, which were sometimes able to capture the reflected light from flanking glass facades. Landmark buildings could be used as focal points of orientation in adjoining urban plazas, grounding each urban space into a network of places. The field of skyscrapers was perhaps not the best example to define the importance of movement in experiencing architecture - no surprise that Giedion did not use it - but the modern space concept of space-time could be applied to it. At least, with the open ground of green vegetation, from which the tall buildings rose like crystals (Le Corbusier's own description, see Le Corbusier 1937/1964, 53), space was given free flow.

\footnotetext{
3 "The materials of city planning are: sky, space, trees, steel and cement; in that order and that hierarchy." The quote is attributed to Le Corbusier in numerous sources, original source mentioned as "in Times 1965". E.g. Weber 2008, 186.

${ }^{4}$ The concept of field has been known in urban planning education for decades. It was used in the Finnish textbook Asuinaluesuunnittelu $(1997,101)$, but more precisely defined as a concept, f. ex., by Stan Allen in his 1997 article, reprinted in Hensel et al. Space Reader (2009).
} 
Le Corbusier's plan for the center of Paris and Eliel Saarinen's for Chicago's lake front were both drafted in the early part of the second decade of the $20^{\text {th }}$ century. The two case examples can give us an idea of how the urban spaces enhanced or even created by tall buildings were dealt with in the early 1920 s by two architect-planners who were branded with the "modern" epithet ${ }^{5}$. Both architects drafted plans as well as wrote about their design ideas. In this study, the main reference material used for researching Le Corbusier's ideas about tall buildings consists of the following: Plan Voisin (1925) and the Contemporary City (La Ville Contemporaine, 1922), Urbanisme (1924) and Vers Une Architecture $(1923)^{6}$. From Eliel Saarinen, the following material has been studied: Chicago Lake Front Plan (1923), The City, Its Growth, Its Decay, Its Future (1943) and The Search for Form in Art and Architecture (1948).

The main plans studied for this article (Le Corbusier's visionary plan for the center of Paris and Eliel Saarinen's designs for the Chicago Lake Front) were both extensively published and included plans and perspective drawings, the drawings being the most informative when studying the spaces resulting from the design choices. To complement the plans, the reference material in this study consists of the two most famous books written by the two studied architects. Their books have similar topics: the city and its future, and then, broadly, architecture. Le Corbusier described his model for renewal of the centers of modern cities in Urbanisme; Saarinen promoted his version of organic decentralization in The City, Its Growth, Its Decay, Its Future. Le Corbusier's Vers Une Architecture was an influential manifesto about the direction modern architecture should take; Saarinen's Search for Form in Art and Architecture was a textbook on design issues, even if it did not give specific instructions for architects. The former books were about the city; therefore, they have been the most important sources of the authors' ideas on urban space. The books about architecture have been used to get additional information on the architects' spatial views - understandably, the descriptions in these books tended to focus on inside space.

\section{The homogeneous space of a field of skyscrapers: Le Corbusier}

As influential as Le Corbusier has been to modernism and the concept of space in modern architecture and urbanism, he has written surprisingly little about it in his two most famous books, Vers une Architecture and Urbanisme. The latter focuses on the urban environment. Nevertheless, one of his best-known quotes on city planning and space cannot be found in this book, nor even the one that had the word space in its title (The New World of Space, 1948). The quote gives a list of the materials needed in city planning: "sky, space, trees, steel and cement" (Le Corbusier cited in Weber 2008, 186). In the quote, vegetation is acting as a buffer between the extensive open spaces and the actual construction materials that make up the buildings. Spatial observations gathered from his drawings support this interpretation.

Eventually, Le Corbusier also wrote a book which had space as its main focus New World of Space (1948). In this book he revealed the specific ability of space to evoke aesthetic emotion. In describing his own experience of encountering the Acropolis, Le Corbusier described architecture that releases vibrations to the surrounding space. Such a space was filled with directed rays or even shouts. Le Corbusier called this space ineffable and seemed in awe of the mystery of it (Le Corbusier 1948, 8, 66). This was a resonating space, and certainly not a void (Vidler 2001, 54).

\footnotetext{
${ }^{5}$ Le Corbusier was, of course, an iconic modern architect, who greatly influenced both architecture and urban planning in the $20^{\text {th }}$ century. Eliel Saarinen had a career in two parts, first in Finland and then United States. He was called a modern architect on several occasions of his career nevertheless, it must be noted that the very word modern changes with changing times.

${ }^{6}$ English versions of Le Corbusier's books: The City of Tomorrow and Towards a New Architecture.
} 
Cornelis van de Ven (1978, 188-190), has seen Le Corbusier's space as an allcontrolling element, even if mass was a main element before space. This assessment is demonstrated in the table of contents of Le Corbusier's book Towards a New Architecture (Vers une Architecture). There are specific chapters titled mass, surface and plan, but not space. Naturally, space was mentioned, as it was included among the elements of architecture (Le Corbusier 1923/1987, 5). The elements were, specifically: light and shade, walls and space. The last element may have needed defining more than the first three, but definitions were sparse. Le Corbusier wrote of spaces and volumes, implicitly assuming that these concepts were familiar to the reader. Or if not, in his opinion, the illustrations of architecture in the past and present would likely clarify the issue. In Le Corbusier's descriptions, the architect, a plastic artist, created volumes, and great spaces were filled with light (Le Corbusier 1923/1987, 181-183, 186, 218).

The materials of city planning are: sky, space, trees, steel and cement; in that order and that hierarchy.

In his book Urbanisme, the scale became vast, the spaces even greater and the light sources more distant. Le Corbusier (1924/1987) called for order and efficiency in city planning, and the tall building was one of the design elements used to achieve this. The urban compositions were axial, with some centripetal possibilities (see Allen 2009, 121). The high-rise building - the skyscraper - he could use as a unit of this urban composition. He wrote about open spaces and referred then to the ground area; there was plenty of unbuilt area left for vegetation in his modern city ${ }^{7}$. His descriptions of space could be from a fastmoving car, from where he could observe the "immensity of space" and note that the "sky is everywhere" (Le Corbusier 1924/1987, 177). Another point of spatial observation was the top of a tall building, where the "spirit is roused to a vital activity", and "optimism fills the mind" (Le Corbusier 1924/1987, 186). He called skyscrapers "look-outs' dominating an ordered world" (Le Corbusier 1924/1987, 187), and was able to demonstrate this interpretation by compelling text, where the city planning elements of sky and space were given significant roles. The space here seems to be something best experienced from a bird's eye view, with an all-controlling gaze. The most famous of Le Corbusier's drawings of his contemporary city are, indeed, such bird's eye views. We are shown a magnificent orthogonally ordered monumentality. The sky is brought close to the observer, space flows around the towers and over the built landscape, where green vegetation and crisp white modern architecture alternate. We can certainly imagine the steel behind the white façades.

Giedion $(1941 / 1974,833)$ saw the high-rise buildings in open space, amidst greenery, proposed by Le Corbusier and colleagues, as an imperative solution for the future of cities. In the green park-like spaces around housing-blocks, he noted a similarity with the tradition of surrounding large houses with pleasure grounds for recreation. This, according to Giedion, reflected "a baroque desire" for greenery. (Giedion 1941/1974, 836-838.) Such desire had been strongly advocated by Le Corbusier, for whom vegetation was one of the sources for human scale in an otherwise monumentally scaled and ordered modern city. A "broad vista" was the aim for a contemporary urban landscape, but in the vast open spaces human beings might feel lost - as Camillo Sitte $(1889 / 2001,53)$ had already noted with his writing of agoraphobic condition. Le Corbusier $(1924 / 1987,237)$ solved the problem of agoraphobia by using vegetation and introducing low-rise buildings of maximum three stories, which he wound around his high-rises in orthogonally meandering rows. With vegetation, the "cheerful" quality was brought to the urban experience. His main ingredients of city planning - sky and space - were prominently visible in the perspectives depicting this urban landscape.

Le Corbusier drafted drawings of his new urban environment from also slightly above pedestrian eye-level. These drawings abound with green vegetation,

\footnotetext{
7 The green areas he saw as "urban landscape" and "cheerful spaces" that offered a "broad vista" two of the three pictures he showed to illustrate the point were taken from above, indeed offering a wide view (see Le Corbusier 1924/1987, 200, 232, 236-237).
} 
echoing the importance of recreational spaces he had mentioned in Urbanisme (Le Corbusier, 1924/1987, 78, 237). In the nature of perspective drawings, these are positioning the stationary viewer at a specific chosen point, to look at an unmoving urban landscape. Movement has to be imagined; the eye must travel beyond the boundaries of the picture. The space these drawings show is immense, freely flowing. The sky is not just an empty background, it is a visualized with clouds and airplanes, giving it an almost material quality. Within this immense space, the details in some of the drawings, for example, a Parisian coffee shop arrangement of tables, chairs, trays and cups, look strangely quaint and even out of place, as if somehow in the wrong scale (figure 1). The modern spatial concept of Le Corbusier's urban drawings seems to require the speed he so exaltedly expressed in his text. The traditional perspective drawings - or any drawings - simply do not do it justice. Contemporary visualizations of flyovers in 3D-models would have suited this urban landscape well.

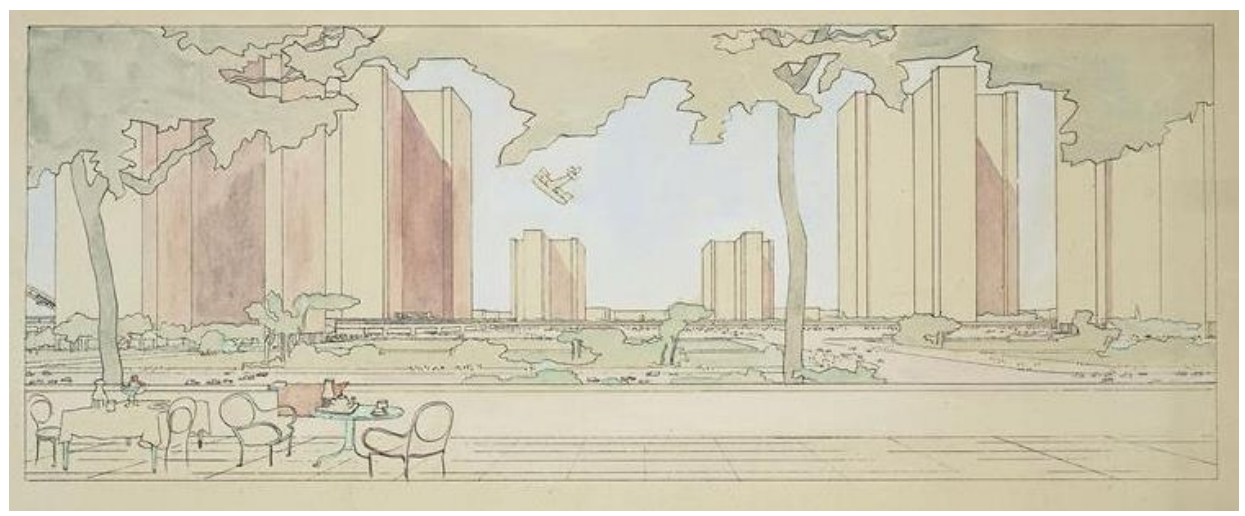

Figure 1. Le Corbusier. A Contemporary City, 1922 (Copyright Fondation Le Corbusier ADAGP). A view from a terraced café. According to Le Corbusier, the terraces "were much frequented and serve as boulevards". The sky and open space are visible in the drawing.

One may imagine a fly-over of a landscape Le Corbusier himself has described, seen from the top of a high-rise building. Such views allow the viewer a feeling of control, and there is a "pleasure of 'seeing the whole'", as Michel de Certeau $(1984 / 1988,92)$ has written of the experience. True to this view, Le Corbusier $(1937 / 1964,90)$ offered an elated appreciation of looking down on the urban landscape under the sky ${ }^{8}$. In the description of a night view over Manhattan from a skyscraper, the two elements he first mentioned as important in city planning - sky and space - are very much present.

The open space of Le Corbusier's city has been called hierarchically homogeneous and rationalized (Hight et al. 2009, 21). The rational order is certainly visible in both his text and drawings. In terms of space, the spectator may imagine moving with considerable speed among the field organized around a composition of tall buildings or observing the city from a high-rise lookout. The tall building gives an urban dweller a possibility to experience two of Le Corbusier's main elements of city planning: sky is brought close and space spread over the landscape receding towards the horizon. However, if the space is homogenous, it is that in spite of the high-rises, not because of them.

8 "The sky is decked out. It is the Milky Way come down to earth; you are in it. Each window, each person is a light in the sky. [...] The stars are part of it also - the real stars - but sparkling quietly in the distance. [...] We are charged with feeling, we are intoxicated, legs strengthened, chest expanded, eager for action, we are filled with great confidence." (Le Corbusier 1937/1964, 90.) 


\section{The composition and urban space on the outside: Eliel Saarinen}

The two books by Eliel Saarinen were published in 1943 and 1948, two decades after Le Corbusier's influential books. Saarinen had, however, started to write architecture texts with publishing likely in mind already in the 1920s, and a manuscript from 1925 contains much of the material published in his 1948 book The Search for Form in Art and Architecture (Saarinen 1925 c.f. Saarinen 1948/1985). In this book space is mentioned several times, although somewhat reluctantly. By the 1940s, modern architecture's focus on space had become so pervasive, that an architect could be critical of its role. Saarinen concentrated on form and seemed almost reluctant to talk about space, writing: "if the word 'space' after all must be mentioned". Nevertheless, he noted that architecture was the art of space in space. (Saarinen 1948/1985, 254.)

When Saarinen mentioned space in a chapter title, he combined it with form. He wrote of rooms as embracing spaces, not just something contained within four walls (Saarinen 1948/1985, 131). There was an underlying organic integrity present, a desired atmosphere that included more than the bare walls - it was a sum of the materials and objects within the space. This may be linked to the concept of a total work of art, Gesamtkunstwerk, which had been the prevalent idea in architecture around the time Saarinen started his professional career, designing buildings and their furnishings in a national romanticist version of Jugendstil (see Hausen 1990, 9, 41). The idea of embracing space could also be seen to imply a spatial understanding as a bodily experience. This is a space where "human life goes on in one form or another" (Saarinen 1948/1985, 131).

In his other book - The City, Its Growth, Its Decay, its Future - Saarinen considered space in the urban dimension. Like Le Corbusier, he saw order as an important factor in city planning. He started with order, adding proportion, rhythm, and material to a list of important considerations, even in the scale of cities. He associated his views with contemporary attitudes to space, noting that "our" modern attitude to space was open, in contrast to the enclosed space of the medieval period. At the same time, however, he was critical of contemporary spatial attitudes, wanting more focus on outside space. This outside space, the space between buildings, was often forgotten, "left outside to vibrate in discordant distress" (Saarinen 1943/1958, 52). Such a space was not simply open, flowing and homogeneous. If this space was not yet a tensioned field of events (see Kuoppamäki 1993, 57), in any case it contained qualities that took it beyond the simple interpretation of homogeneous space.

Moreover, what did the tall building bring to the discussion of qualities of urban space? Although the main goal of Saarinen's book The City, Its Growth, Its Decay, its Future was the promotion of decentralization, the issue of urban space was mentioned several times, directly or indirectly, often in connection with tall buildings (see Saarinen 1943/1958, 167-169, 185-187). The functionalist demands for air, light and space would alone have demanded that Saarinen also dealt with spatial issues. For him, the skyscraper was not a necessary urban design unit, but a signal of progress that had possibilities as a focal point in an urban composition (Saarinen 1943/1958, 169, 186). This attitude towards the tall building type had already been apparent in the early 1910s, when Eliel Saarinen had used tall buildings as landmarks in his urban plans (for example: Tallinn Plan, Munkkiniemi-Haaga Plan in Helsinki and Canberra plan for Australia's capital). The tall building's role had been a landmark in the compositions. An accompanying text supports this view, even if Saarinen also allowed for a favorable grouping of tall buildings (Saarinen 1912, 12; cf. Saarinen 1943/1958, 196-197). His attitude towards this building type did not change after his $2^{\text {nd }}$ prize winning entry for the Chicago Tribune Tower competition of 1922, when he designed an actual skyscraper. The same view was expressed again three decades later in his book on decentralization. According to Saarinen, overall planning issues took precedence when tall 
buildings were used (Saarinen 1943/1958, 196-197). Thus, the skyscraper was put to best use when it was a focal point in the composition.

As a focal point, the tall building was also a place of observation. Like Le Corbusier, Saarinen (1943/1958, 192-193) described views of Manhattan, having been impressed by the "lofty skyscraper masses" of the vertical city. They seemed to concentrate the very life of the active, restless city. He admired the silhouette and panorama available from the tops of skyscrapers, describing the majestic picture: "when myriads of lights dot the black curtain of night and the stars of man blend into the sparks of heaven". The description is similar to the one written by Le Corbusier six years before, where he compared the city lights sparkling below to "Milky Way come down to earth" (Le Corbusier 1937/1964, 90). In his text for the Chicago Lake Front Plan of 1923, Saarinen had already used the view from the top of a skyscraper. In the text, he follows a traveler from an underground railway to the highest floor of the skyscraper hotel. He then proceeds to describe the panorama of the city. The main plaza, surrounded by flowerbeds and public buildings, expands underneath in monumental tranquility. Plenty of greenery is visible from such an observation point, "high above the city's smoke and dust." (Saarinen 1923b, 487-514.) Noticeable in this description, which stretches across the urban landscape towards the horizon, is the absence of other tall buildings, bar one. A visual line of connection is established between the two pinnacles, accentuating their landmark status. The space is directional, as well as open and continuous.

This description was not complemented by the view from ground up. For this view, we must rely either on Saarinen's later text illustrating the Manhattan streetscape ${ }^{9}$ or an earlier response to a newspaper journalist, after the Chicago Tribune Tower competition. When asked about the architecture of skyscrapers, he answered that the verticality of the tall building should be observable from the street, along the façade ("Europe wakes up to the need of U.S. skyscraper", Chicago Daily Tribune, 23.1.1923). This would imply that his idea of the skyscraper's role would not be just a landmark. If observable both from afar in the landscape and from the street level next to a plaza, the tall building has a specific role: it marks the situation of a public space in the city. The building forms a boundary to the space, but more importantly, the buildings and the space form a spatial point in the urban landscape. The public space would otherwise not be visible when the city is observed from above or when walking in the maze of its streets. The tall building becomes a grounding element for a space of gathering.

In many of Eliel Saarinen's drawings of high-rises in the urban landscape, the tall buildings were used in a similar fashion as grounding elements (figure 2). Space did not flow freely around them. The tall buildings were connected to other, smaller buildings, and to public plazas, which were at least partially enclosed - all in the manner of traditional urban form and spatial typologies. This was not in opposition to the simplistic homogeneous view of modern urban space, but rather illustrated a more diverse understanding of it.

\footnotetext{
${ }^{9}$ Saarinen called Manhattan a steel and stone forest. He took the reader to Central Park, describing the colorful silhouette that encloses this urban space, and then to the narrow dark streets, "with sunlight cutting its golden streams through those deep shadows", Saarinen 1943/1958, 192-193.
} 


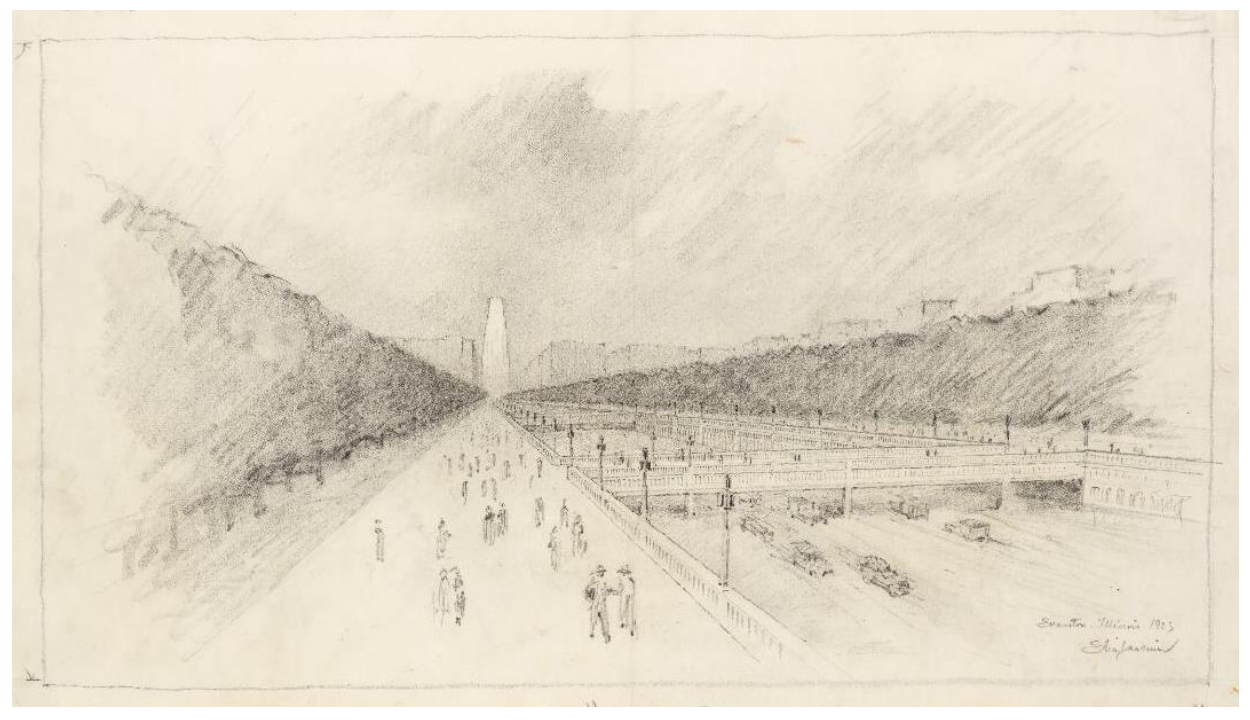

Figure 2. Eliel Saarinen. Lake Front Plan, Chicago, USA, 1923 (Museum of Finnish Architecture, CCBY 4.0). Sunken traffic artery through Grant Park. The tall building has a landmark role in this drawing, drawn above eye-level with a controlling gaze.

\section{Revisiting modern urban space: homogeneous and heterogeneous}

In the current Finnish context, the effects of tall buildings on surrounding microclimate or wind conditions have been noted in several studies for high-rise construction in Finnish cities (for a condensed account, see Chudoba 2019), but actual spatial implications of the construction of tall buildings have not been a focus. The issue is important for an inhabitant experiencing the created spaces, and naturally requires an understanding of space as a design element. As such, a complex view of space gives an opportunity for complex design possibilities the modern homogeneous space and the added diversity of heterogeneous space need not cancel each other.

Modern architects were not unanimous in their application of spatial theory; the two studied cases illustrate the variety of interpretations of modern space. Both architects embraced the new contemporary concept of open and continuous space, but space was more varied than the adjectives would lead one to believe. Their texts - supported by the visual material - imply an idea of space that is not simply homogeneous, but already more complex in interpretation. As Hight, Hensel, and Menges $(2009,20)$ have noted, a single definition of space cannot characterize modernity. This was also true inside the architectural profession, where space was used in all its three roles: as a philosophical concept, an architectural quality, and a problem around which architecture is given form (Hight et al. 2009, 20).

The three roles could be used all at once, creating a possibility of constantly shifting spatial viewpoints in the design process. Thus, describing modern space as open and homogeneous is one facet of this important design element and concept, but a simplified general interpretation needs to be complemented with other views. Anthony Vidler $(2001,12)$ has even coined warped space, to gather the many spatial concepts of modern culture under one term. The concept is based on the idea of space-related phobias which are seen as a base of modern man's attitudes to space (Vidler 2001, 2). With warped space, single definitions are cast aside to allow for a spatial understanding that stretches through the decades of the $20^{\text {th }}$ century, finally to end with the techniques of digital images and virtual reality (Vidler 2001, 12). The concept of heterogeneous space, however, is a direct answer to the perceived shortcomings of homogeneous space. It has paved the way for a spatial theory beyond simply homogeneous space, offering necessary complexity to 
interpretations of architectural space. This is especially important in the urban scale, where scalar variety and degrees of publicity are considerable. A complex view of space is also needed when studying the role of tall buildings in an urban environment.

The concept of heterogeneous space has been much influenced by Michel Foucault's writing. He has called modern space empty and claimed that we do not live in a homogeneous space. For Foucault, heterogeneous space is a space of shifting qualities - there is no void, but sites defined by different sets of relations. (Foucault 1984, 2-3, citing Bachelard's Poetics of Space as argumentation.) Heterogeneous space recognizes differences (Hensel et al. $2009,7)$. It seems to be less about form, more about performance; less about physical structures, more about flows around them, through them. If the idea of modern space as simply open and continuous, immaterial, and homogeneous is a simplistic view, then traces of more complex interpretations could be looked for in the work of architects who were labeled modern during their careers. While a variety of discovered viewpoints towards space may not indicate that the space concepts were also non-homogeneous, this possibility must be considered.

The two architects studied here had both differences and similarities in their attitudes to space. They certainly saw the possibilities of a vertical city differently. Nevertheless, they shared ideas of a contemporary vision of urban space. The skyscraper had a subordinate role in their cities. Both architects used this building type as an element in the monumental urban composition, even if they had separate views about its role. For Le Corbusier the skyscraper was a multipliable building block, for Eliel Saarinen, an urban focal point. The spatial implications of these different views were naturally dissimilar. Space was openly flowing around the building blocks, each separate in the loosely woven but organized urban fabric. In contrast, with a more tightly woven fabric of both open and enclosed spaces, if a building was to be visible as a helpful point of orientation, it needed noticeable verticality in its context.

In his text illustrating modern space-time feeling, Le Corbusier was speeding across the urban landscape, if not actually behind the steering wheel of a car, at least figuratively (Le Corbusier 1924/1987, xxiii). Saarinen, on the other hand, was concerned about the neglected spaces between the buildings (Saarinen 1943/1958, 52) - this was likely a pedestrian view. Indicative of their attitudes, these sentences on urban issues are fragments of their texts, which included a considerable amount of material on the topic important for this article: the tall building and urban space.

Although Le Corbusier's urban space has been called hierarchically homogeneous, as well as rationalized and interchangeable (Hight et al. 2009, 21) or even ineffable and transparent (Vidler 2001, 54, 62), his descriptions of it differ depending on the context. With these varying viewpoints, space transforms and scales become diversified. With movement, space gets direction and speed affects the way it is experienced. With the master planner attitude, Le Corbusier also took readers to the top of a tall building, to observe the urban landscape in its entirety. Here, his two main elements of city planning - sky and space - were readily observable. From above it was possible to experience the open, extending space. In addition, Le Corbusier could also see space with closed and contracted, even resonating qualities (Le Corbusier 1948 cited in Vidler 2001, 54-55), hinting at non-homogeneity.

Saarinen also used the vantage point from top of the skyscraper in his text. Nevertheless, the most intriguing spatial descriptions in Saarinen's text are not necessarily from above, but observed from the street, or even confined inside a building: the idea of distressed urban space and the embracing space of a room. 
The distressed urban space of Saarinen's description could be linked to the urban detritus that Albert Pope (1997/2009, 65-66) has mentioned in Ladders. These spaces - the vast unoccupied and neglected residue, the parking lots, carscapes, abandoned lots and buffer zones - could also offer possibilities for urban regeneration, or even reinvention. In this context, Pope brings forth the concept of tabula rasa. The blank slate or scraped tablet, in urban terms a cleared piece of land, was an ideal base for modernism's projects. Pope stresses the "unbridled potential" this idea brings to urban planning, implying that at the same time, depth and meaning were given to modern urban space, space released from the shackles of form. (Pope 1997/2009, 65-66.)

The adjective "distressed", used by Saarinen, or similarly, the "resonating" qualities mentioned by Le Corbusier, could very well be attached to the neglected spaces of modern cities, implying a dire need, not only a possibility, for reinvention. In Saarinen's case, the constraints of form were never completely detached from the idea of modern space. Instead, he intertwined them. One could say that he even carried the Sittean ideal of enclosed space to his version of the modern city spaces, fitting interior space, the embraced space, to another scale in the urban context.

The simple interpretation of modern urban space offered by Sigfried Giedion, first in the 1940s, has since been transformed to a spatial field with a variety of qualities. Movement defined space-time, but the open, continuous and freeflowing homogeneous space was somewhat monotonous by nature. Now, in contrast, space may be described by a dichotomy of opposites. It is both homogeneous and heterogeneous, as well as animated and inert, monotonous and varied (Pope 1997/2009,65), or even social, abstract, smooth or striated (Vidler 2001, 12, with reference to Lefebvre and Deleuze).

\section{Conclusion}

The urban landscape in all its scales offers a variety of spatial experiences, to which one particular building type, the high-rise, may contribute in different ways, depending how it is used in the urban composition. It may be a lookout, offering views of infinitely extending space from above, to be appreciated collectively. Or it may be a grounding element, point of orientation, signaling the location of a public space in the city. In the latter role, tall buildings can be visually prominent accents marking the network of public spaces, while individually capable of directing spatial flows. A controlled cluster of high-rises, perhaps resembling a modernist field of towers, may provide a collage of spatial experiences, from enclosed to more openly flowing, from individual to collectively experienced. Tall buildings are, more often than not, connected to public spaces or even providing semi-public spaces, which can be seen as extensions of urban dwellers' homes. In any case, the tall building affects its surroundings spatially, both in the immediate vicinity and in a more distant view. Different qualities are attached to space depending on how the tall building is seen in its context. When it is designed for a particular spot in the city, the architect-planner of today continues to make choices about its role - and the choices are affected by a variety of spatial possibilities.

With spatial attitudes that allow for complexity, the tall building offers possibilities as an urban design element that go beyond questions of skyline and visibility. As more high-rises are being constructed in Finnish cities, the issue of space should be observable in the actual urban experiences, and thus provoke discussion. Space could, after all, resonate either positively or negatively in the urban environment. 


\section{References}

Allen, S., 1997. "From object to field: Field Conditions in Architecture and Urbanism". In M. Hensel, C. Hight \& A. Menges, eds. 2009. Space Reader. Heterogeneous Space in Architecture. Chichester, West Sussex: John Wiley and Sons. Pp. 118-143.

Bachelard, G., 1958. The Poetics of Space. Translated from French by M. Jolas, 1969. Boston: Beacon Press.

de Certeau, M., 1984. The Practice of Everyday Life. $1^{\text {st }}$ paperback ed. 1988. Berkeley, Los Angeles \& London: University of California Press.

Christ-Janer, A., 1948. Eliel Saarinen. Revised edition, 1979. Chicago \& London: The University of Chicago Press.

Chudoba, M., 2011. Kaupunkia etsimässä. Eliel Saarinen Amerikassa 19231950 (Search for a City. Eliel Saarinen in America 1923-1950). Tampere University of Technology, School of Architecture. Publication 6.

Chudoba, M., 2019. "Looking Up: Imagining a Vertical Architecture". In A.-E. Toft, M. Rönn \& E. Smith Vergeland, eds. 2019. Reflecting Histories and Directing Futures. NAAR Proceedings Series 2019-1. Pp. 99-124.

Cohen, J-L., 1995. Scenes of the World to Come: European Architecture and the American Challenge, 1893-1960. Paris: Flammarion and Montreal: Canadian Centre for Architecture.

Collins, P., 1965. Changing Ideals in Modern Architecture 1750-1950. London: Faber and Faber Limited.

"Europe wakes up to the need of U.S. skyscraper", Chicago Daily Tribune, 23.1.1923.

Foucault, M., 1984. "Of Other Spaces, Heterotopias". Translated from French "Des Espace Autres". In Architecture/Mouvement/Continuité, October 1984, based on a 1967 lecture by Michel Foucault. Available through: http://foucault.info/documents/heteroTopia/foucault.heteroTopia.en.html [Accessed 1 February 2006].

Giedion, S., 1941. Space, Time \& Architecture. The Growth of a New Tradition. $6^{\text {th }}$ ed., 1974. Cambridge, Mass.: Harvard University Press.

Hara, H., 1975. "Space as Culture: Essay on Homogeneous Space". In Shiso (Thought), Aug-Sept 1975. Published also as "Essay on Homogeneous Space" in H. Hara. 1987. Space: From Function to Modality. Tokyo: Iwanami Shoten.

Hausen, M., 1990. "Saarinen Suomessa" (Saarinen in Finland). In M. Hausen, K. Mikkola, A.-L. Amberg \& T. Valto, 1990. Eliel Saarinen, Suomen aika. Helsinki: Otava. Pp.7-82.

Hausen, M., Mikkola, K., Amberg, A-L. \& Valto T., eds., 1990. Eliel Saarinen, Suomen aika. Helsinki: Otava.

Hensel, M., Hight, C., \& Menges, A., eds., 2009. Space Reader. Heterogeneous Space in Architecture. Chichester, West Sussex: John Wiley and Sons.

Hight, C., Hensel, M. \& Menges, A., 2009. "En route: Towards a Discourse on Heterogeneous Space beyond Modernist Space-Time and Post-Modernist Social Geography". In M. Hensel, C. Hight \& A. Menges, eds. 2009. Space 
Reader. Heterogeneous Space in Architecture. Chichester, West Sussex: John Wiley and Sons. Pp. 9-37.

Jalkanen, R., Kajaste, T., Kauppinen, T., Pakkala, P. \& Rosengren, C., 1997. Asuinaluesuunnittelu (Planning of housing areas). Helsinki: Rakennustieto.

Kruft, H.-W., 1985. A History of Architectural Theory from Vitruvius to the Present. Translated from German by R. Taylor, E. Callander \& A. Wood, 1994. New York: Princeton Architectural Press.

Kuoppamäki, R., 1993. Arkkitehtonisen tilan aineellisuus. Johdatus kaupungin uudelleen ajatteluun (The materiality of architectural space. Rethinking the city). Helsinki University of Technology. Publications in Architecture 4/1993.

Lapintie, K., 2017. "Ei ole avaraa", blog text 26.11.2017. Available through: http://mahdollisetkaupungit.blogspot.com/search?updated-max=2018-07-

26T04:36:00-07:00\&max-results=7. [Accessed 2 July 2019]

Le Corbusier, 1922. A Contemporary City (Ville contemporaine pour trois millions d'habitants, sans lieu, 1/5, drawing number 29711). Copyright Fondation Le Corbusier - ADAGP.

Le Corbusier, 1923. Towards a New Architecture. Translated from French by F. Etchells, 1987. London: The Architectural Press.

Le Corbusier, 1924. The City of Tomorrow. Translated from French by F. Etchells, 1987. London: The Architectural Press.

Le Corbusier, 1937. When the Cathedrals Were White. Translated from French by F. E. Hyslop, Jr., 1964. London: McGraw-Hill Book Company.

Le Corbusier, 1948. New World of Space. New York: Reynal and Hitchcock and The Institute of Contemporary Art, Boston.

Van Leeuwen, T. A. P., 1988. The Skyward Trend of Thought. The Metaphysics of the American Skyscraper. $2^{\text {nd }}$ ed. 1990. Cambridge, Mass.: The MIT Press.

Mitrović, B., 2004. "Leon Battista Alberti and the Homogeneity of Space", Journal of the Society of Architectural Historians, Vol 63, No. 4, Dec 2004, pp. 424-439.

Pope, A., 1997. "Mass Absence", Ladders. Reprinted in M. Hensel, C. Hight \& A. Menges, eds. 2009. Space Reader. Heterogeneous Space in Architecture. Chichester, West Sussex: John Wiley and Sons. Pp. 52-71.

Saarinen, E., 1912. "International Competition for Design of Federal Capital. Report accompanying design submitted by Eliel Saarinen, of Helsingfors". Series accession number CP487/6/1. Collections of the National Archives of Australia and the National Library of Australia. Available through: http://naa12.naa.gov.au/scripts/imagine.asp [Accessed 1 July 2016].

Saarinen, E., 1923a. "Chicago Lake Front", Drawings 014/2 - 014/11,014/13, 014/15 - 014/17, 014/19, 014/22,014/43. Original drawings, Museum of Finnish Architecture.

Saarinen, E. 1923b. "Project for Lake Front Development of the City of Chicago", American Architect 124, number 2434, 1923. Pp. 487-514, editorial comment p. 515.

Saarinen, E., 1925. Untitled manuscript. Parts: 1. Investigation of the innermost soul of architecture, 2. The guiding principles of architectural education \& 3 . Organization of Cranbrook. Museum of Finnish Architecture. 
Saarinen, E., 1943. The City. Its Growth, Its Decay, Its Future. $4^{\text {th }}$ ed. 1958. New York: Reinhold Publishing Corporation.

Saarinen, E., 1948. The Search for Form in Art and Architecture. Republished ed. 1985. New York: Dover Publications.

Sitte, C., 1889. Kaupunkirakentamisen taide. Translated from German by J. Kalanti 2001. Helsinki: Rakennusalan kustantajat RAK.

Suomen hypoteekkiyhdistys. 2018. Hypon asuntomarkkinakatsaus (Hypo housing market report), November 2018. Available through: www.hypo.fi/wpcontent/.../11/Hypon-Asuntomarkkinakatsaus marraskuu2018.pdf [Accessed 2 July 2019].

Suomen ympäristökeskus (Finnish Environment Institute). 2017. Asukasbarometri 2016 (Resident barometer). Available through: https://www.ymparisto.fi/asukasbarometri [Accessed 2 July 2019].

Taut, B., 1919. "The City Crown". Translated from German by U. Altenmüller \& M. Mindrup, 2009. In: Journal of Architectural Education, pp. 121-134, 2009. Copyright ACSA. Available through: http://socks-studio.com/2013/09/28/brunotaut-the-city-crown-1919/ [Accessed 12 April 2017].

Van de Ven, C.,1978. Space in Architecture. Assen: Van Gorcum.

Vidler, A., 2001. Warped Space. Art, Architecture and Anxiety in Modern Culture. Cambridge, Mass. \& London, England: The MIT Press.

Wakabayashi, M., 2019. "Poking Holes in Modern Space". In Canadian Centre for Architecture/ Meanwhile in Japan, CCA c/o Tokyo project. Available through: https://www.cca.qc.ca/en/articles/72728/poking-holes-in-modern-space [Accessed 14 August 2020].

Weber, N. F., 2008. Le Corbusier - A Life. New York: Alfred A. Knopf. 